\title{
Withering syndrome in the abalone Haliotis diversicolor supertexta
}

\author{
Thanitsara Wetchateng ${ }^{1, *}$, Carolyn S. Friedman ${ }^{2, *, * *}$, Nathan A. Wight ${ }^{2}$, Pei-Yu Lee ${ }^{3}$, \\ Ping Hua Teng ${ }^{3}$, Siriporn Sriurairattana ${ }^{4}$, Kanokphan Wongprasert ${ }^{1}$, \\ Boonsirm Withyachumnarnkul ${ }^{1,4}$
}

\author{
${ }^{1}$ Department of Anatomy and ${ }^{4}$ Center of Excellence for Shrimp Molecular Biology and Biotechnology (Centex Shrimp), \\ Faculty of Science, Mahidol University, 272 Rama 6 Rd., Bangkok 10400, Thailand \\ ${ }^{2}$ School of Aquatic and Fishery Sciences, University of Washington, Seattle, Washington 98195, USA \\ ${ }^{3}$ Institute of Medical Biotechnology, Central Taiwan University of Science and Technology, No. 11, Buzih Lane, \\ Taichung City 40601, Taiwan, ROC
}

\begin{abstract}
Abalone aquaculture is a small but growing industry in Thailand and is based on both the exotic Haliotis diversicolor supertexta and the native $H$. asinina. Withering syndrome (WS) in abalone is caused by an infection with the Rickettsia-like organism (RLO) 'Candidatus Xenohaliotis californiensis' and has been spread to many countries globally. The present study reports the first observation of the WS-RLO agent in the small abalone, H. diversicolor supertexta in Thailand, Taiwan (ROC) and the People's Republic of China (PRC). Under light microscopy, the RLO was observed as intracytoplasmic inclusions within epithelial cells lining the post-esophagus and, to a minor extent, the intestine of $H$. diversicolor. Under transmission electron microscopy, inclusions were characterized as colonies of rod-shaped bacteria, $200 \times 1800 \mathrm{~nm}$ in size, within a vesicle in the cytoplasm of the infected cell. The RLO from the small abalone bound with WS-RLO-specific in situ hybridization probes and was amplified by polymerase chain reaction (PCR), using primers designed from the $16 \mathrm{~S}$ rDNA sequence of the original WS-RLO from California, USA. The PCR product of RLO samples from both the PRC and Thailand showed extremely high identity with the California WS-RLO (100 and $99 \%$, respectively). These data combined with the history of abalone movements for aquaculture purposes indicate that RLOs observed in Thailand, Taiwan and the PRC are the WS-RLO that originated from California.
\end{abstract}

KEY WORDS: Haliotis diversicolor · 'Candidatus Xenohaliotis californiensis' · 16S rDNA · Abalone · Withering syndrome $\cdot$ Thailand · Taiwan $\cdot$ People's Republic of China $\cdot$ California

Resale or republication not permitted without written consent of the publishe

\section{INTRODUCTION}

Culture of the small tropical abalone Haliotis diversicolor supertexta is an emerging commercial industry in several Asian countries such as in Taiwan, Thailand and southern China because of its high market potential. The first commercial abalone farm was started in 1996 in southern Thailand on Phuket Island. Currently, most of the abalone farms ( $\mathrm{n}=5$ to 6 ) in Thailand culture the native species $H$. asinina, as it has the highest meat yield of the 3 native Thailand haloitids (Klinbunga et al. 2004); another 2 or 3 farms culture the imported species $H$. diversicolor supertexta (Jarayabhand et al. 2009) due to its high market demand (P. Jarayabhand, Chulalongkorn University, Thailand, pers. comm.). Thailand abalone production is currently low, with an estimated annual yield of from 60 to 100 metric tonnes (P. Jarayabhand pers. comm.). As with many developing aquaculture sectors, growth of the industry is accompanied by the movement of animals among locations, which can result in the transfer of pathogens along with the target host species. It is important to know if potential pathogens, such as the 
rickettsial agent of withering syndrome (WS) are present in abalone under culture. Prior to the present study, the infection of Asian abalone species by Rickettsia-like organisms (RLOs) had not been observed or described; however, such knowledge is needed for the successful development and expansion of abalone aquaculture in Asia.

WS is a catastrophic disease, caused by the intracellular RLO 'Candidatus Xenohaliotis californiensis' (Friedman et al. 2000). WS affects a variety of abalone species and was first observed in populations of wild black abalone Haliotis cracherodii in the mid-1980s (Haaker et al. 1992). Affected black abalone had an atrophied foot muscle and high mortality rates, especially in populations off southern California, USA (Haaker et al. 1992). The disease progressively spread throughout southern and central California (Haaker et al. 1992, Altstatt et al. 1996, Moore et al. 2000, Friedman \& Finley 2003, Miner et al. 2006). By 1992, WS was associated with population declines on 6 of the 8 Channel Islands, with losses of up to $99 \%$ of $H$. cracherodii (VanBlaricom et al. 1993, Tissot 1995). These losses led, in part, to an initial closure of the California black abalone fishery in 1993, followed by total closure in 1997 (Haaker et al. 2001). Losses due to WS vary among host species from extremely high losses in white abalone (Friedman et al. 2007) to moderate losses in red abalone (Moore et al. 2000) and low to moderate losses in green and pink abalones (Tinajero et al. 2002, Vilchis et al. 2005, Moore et al. 2009). In Baja California, Mexico, $32.5 \%$ of pink and $27 \%$ of green abalones examined had clinical signs of WS (Tinajero et al. 2002). However, green abalone only showed signs of WS when held at elevated temperatures, e.g. $25^{\circ} \mathrm{C}$ (Garcia-Esquivel et al. 2007), but not when held at $18^{\circ} \mathrm{C}$, a temperature at which black and red abalones typically succumb to WS (Friedman et al. 2002, Moore et al. 2009).

We conducted a pilot survey of the small abalone from several Asian countries in an attempt to discern if the WS-RLO was present in the sampled populations. The present study reports on the first case of observed WS-RLO infection in Haliotis diversicolor supertexta.

\section{MATERIALS AND METHODS}

Specimens. Thirty-six small abalone Haliotis diversicolor supertexta measuring $11.09 \pm 4.4 \mathrm{~g}$ in body weight $(\mathrm{BW})$ and $39.4 \pm 5.8 \mathrm{~mm}$ in maximum shell length were collected in March and April 2006 from commercial farms in southern Thailand, in HuiZhou City, GuangDong Province, People's Republic of China (PRC), and in TouCheng Township, YiLiang County, Taiwan, as outlined in Table 1.
Table 1. Haliotis diversicolor. Diagnostic testing results for withering syndrome-Rickettsia-like organism (WS-RLO) detection in abalone, using 4 detection methods

\begin{tabular}{|lccc|}
\hline Method & Origin & No. tested & No. positive \\
\hline Light microscopy & Thailand & 22 & 12 \\
& PR China & 6 & 3 \\
& Taiwan & 8 & 4 \\
In situ hybridization & Thailand & 7 & 7 \\
& PR China & 3 & 3 \\
& Taiwan & 4 & 4 \\
Polymerase chain & Thailand & 22 & 12 \\
reaction & PR China & 6 & 4 \\
& Taiwan & 8 & 6 \\
Transmission & Thailand & 5 & 5 \\
electron microscopy & & & \\
\hline
\end{tabular}

The abalone had been reared in ambient seawater ranging from 27 to $29^{\circ} \mathrm{C}$. All individuals, which appeared normal by gross examination, were sacrificed by severing of the cerebral and pedal ganglia with a scalpel blade prior to excision of post-esophagus, digestive gland, intestine and foot muscle. The tissues were preserved and processed for light microscopy (LM), in situ hybridization (ISH), transmission electron microscopy (TEM) and for polymerase chain reaction (PCR) as described below.

Histology and ISH. The number of samples processed for each method is shown in Table 1. For LM

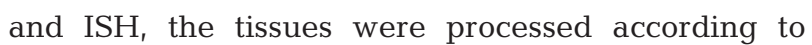
Friedman et al. $(1997,2002)$ and Antonio et al. (2000), respectively. Briefly, tissues were fixed in invertebrate Davidson's solution (Shaw \& Battle 1957) for $24 \mathrm{~h}$, transferred to $70 \%$ ethanol, and processed for routine paraffin histology. For LM, deparaffinized tissue sections $(5 \mu \mathrm{m})$ were stained with hematoxylin \& eosin (H\&E) and viewed by light microscopy. RLO infections were rated at $200 \times$ magnification according to the logarithmic scale of Friedman et al. (1997), in which no visible RLO is rated as 0,1 to 10 RLO inclusions per field of view is rated as 1,11 to 100 inclusions per field is rated as 2 and $>100$ inclusions is rated as 3 . For ISH, the sections were placed on positively charged microscopic slides (Fisher Scientific) and processed according to Antonio et al. (2000), with the exception that we employed a probe labeled with digoxigenin (DIG) via PCR according to the manufacturer's instructions (PCR DIG probe Synthesis Kit, Roche Applied Sciences). Tissue sections from known WS-RLO-infected red abalone Haliotis rufescens served as positive controls. Tissue sections identically treated, but lacking the DIG-labeled probe, served as negative controls. The 
sections were examined under LM; cells showing a hybridized RLO-DNA probe displayed dark-blue to dark-purple precipitates.

TEM. Tissues were preserved in $4 \%$ glutaraldehyde in $0.15 \mathrm{M}$ Millonig's phosphate buffer ( $\mathrm{pH} 7.4$ ) supplemented with $1 \% \mathrm{NaCl}$ and $0.5 \%$ sucrose overnight at $4^{\circ} \mathrm{C}$, rinsed twice with Millonig's buffer and post-fixed in $1 \% \mathrm{OsO}_{4}$ in the same buffer at $4^{\circ} \mathrm{C}$ for $1 \mathrm{~h}$. Samples were then washed in Millonig's buffer and dehydrated at room temperature through a graded series of ethanol. Dehydrated tissues were incubated in propylene oxide and embedded in Epon (EMS). Semithin sections were stained with $1 \%$ toluidine blue (in $1 \%$ aqueous sodium borate) and observed under LM for the presence of potential lesions. Subsequently, ultrathin sections were stained with uranyl acetate and lead citrate and observed by TEM (Hitachi H7500).

PCR and sequence analysis. Amplification of RLO DNA was used as a proxy for RLO infection. A $160 \mathrm{bp}$ fragment of the 16S rDNA of the RLO was amplified in $20 \mu$ reactions containing $2 \mu$ template, $1.6 \mathrm{U}$ of Taq DNA polymerase in $1 \times$ Storage Buffer A (Promega), $1.5 \mathrm{mM} \mathrm{MgCl}_{2}, 200 \mu \mathrm{M}$ dNTPs, $400 \mathrm{ng} \mathrm{m}^{-1} \mathrm{BSA}_{\text {, and }}$ $0.5 \mu \mathrm{M}$ of primers RA 3-6 and RA 5-1 (Andree et al. 2000). Cycle conditions included an initial denaturation step at $95^{\circ} \mathrm{C}$ for $5 \mathrm{~min}$, followed by 40 cycles at $95^{\circ} \mathrm{C}$ for $1 \mathrm{~min}, 62^{\circ} \mathrm{C}$ for $30 \mathrm{~s}$ and $72^{\circ} \mathrm{C}$ for $30 \mathrm{~s}$ and $\mathrm{a}$ final elongation step of at $72^{\circ} \mathrm{C}$ for $10 \mathrm{~min}$. Amplified fragments were separated on a $1 \%$ agarose gel that contained ethidium bromide and visualized on an ultraviolet transilluminator. Amplified PCR fragments from 8 Thailand abalone and 4 PRC abalone were directly sequenced at the University of Washington's Department of Biochemistry DNA Sequencing Facility (Seattle, Washington) using a 3730XL DNA analyzer (Applied Biosystems). Consensus sequences for Thailand samples and PRC samples were obtained using a Sequencher software program (Genecodes). Consensus sequences were aligned with the USA sequence available from GenBank (Accession No. AF133090) via multiple sequence alignments using ClustalW (Thompson et al. 1994).

\section{RESULTS}

\section{Histology}

Basophilic (violet to purple) RLO inclusions were observed in 19 of 36 abalone Haliotis diversicolor examined by histology; approximately $50 \%$ of the abalone examined from each country was infected (Table 1). RLO infection intensities in the post-esophagus and intestine were rated as Grade 2 (19.9 \pm 6.3 inclusions per $20 \times$ field of view), which were consid- ered light to moderate infections (Table 1, Fig. 1a, b; Friedman et al. 1997). Only one abalone had RLO inclusions in the intestine (Fig. 1c). Inclusions were situated apical to the nucleus of the host cells, were mostly spherical or oval in shape, and measured from 5 to $30 \mu \mathrm{m}$ in size. Presence of inclusions caused an expansion of the infected epithelial cell, the microvilli of which retained normal features (Fig. 1b). The intestine of the RLO-infected $H$. diversicolor supertexta revealed an intact epithelial cell structure containing RLOs in the cytoplasm. The myofibers of all foot muscles examined were abundant and tightly packed, with little or no intervening space or signs of atrophy (Fig. 1d).

\section{ISH}

The ISH revealed positive hybridization signals in the epithelial cells of the post-esophagus in all 14 abalone tested that also had histological signs of WSRLO infection (Table 1, Fig. 2a). One abalone from Thailand also showed ISH evidence of infection in the intestine (Fig. 2b). ISH-labeled inclusions ranged from 1 to $2 \mu \mathrm{m}$ to $>15 \mu \mathrm{m}$ in size and were clearly distinguished from the light background. In most infected cells, only 1 colony was observed; however, 2 to 3 colonies were occasionally observed within a single host cell. The positive control, tissue sections from a known RLO-infected red abalone Haliotis rufescens, clearly demonstrated the presence of a positive reaction in the cytoplasm of the epithelium (Fig. 2c). Tissue sections from RLO-infected $H$. diversicolor supertexta fully processed through ISH, but lacking the 16S rRNA probe, did not produce the characteristic DIG-brown precipitate and were considered negative (Fig. 2d).

\section{TEM}

Examination of thin sections of post-esophagus tissues from 5 infected Haliotis diversicolor supertexta that contained intra-cytoplasmic inclusions (Table 1) revealed the presence of abundant rod-shaped microorganisms with mean $( \pm \mathrm{SD})$ lengths of $0.4 \pm 0.14$ to $1.7 \pm 0.32 \mu \mathrm{m}$ (Fig. 3). The bacteria were localized within membrane-bound cytoplasmic vacuoles of the host cell (Fig. 3b) and exhibited ultrastructural characteristics of prokaryotic cells, including a trilaminar cell wall, an electron-dense periplasmic ribosome zone and a nucleoid (Fig. 3c). The cell wall ( 50 nm in width) was composed of the outer membrane surface, the middle electron-lucent layer and the inner membranous layer, which was thicker than the outer layer; a peptidoglycan layer was not visible. 


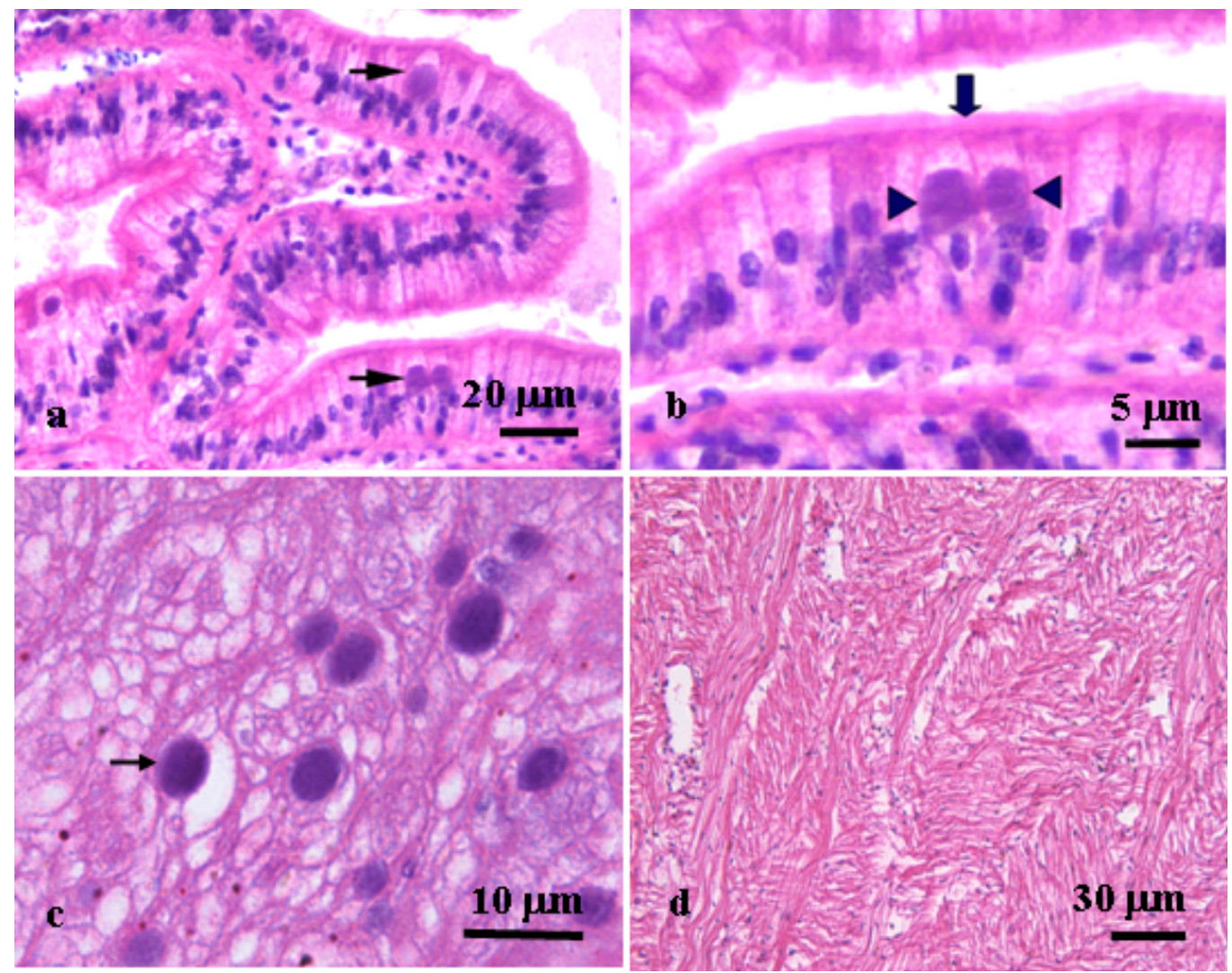

Fig. 1. Haliotis diversicolor supertexta. Photomicrographs of the post-esophagus of abalone from Thailand showing (a) basophilic intra-cytoplasmic inclusions (arrows), which (b) are magnified (arrowheads) and show the intact microvilli of the epithelial cells (arrow). (c) Inclusions were also observed in an intestine of 1 out of 19 individuals (arrow). (d) Foot muscle shows normal muscle fibers

\section{PCR and sequence analysis}

PCR and sequence analyses in the abalone provided further confirmation of the presence of the WS-RLO in 22 out of 36 abalone tested (Table 1, Fig. 4a). DNA from all the individuals that contained morphological evidence of infection (by LM, TEM and ISH) and an additional 3 samples lacking visible RLO inclusions (22 abalone total) amplified the expected $160 \mathrm{bp}$ product. The RLOs from China and Thailand abalones showed 100 and $99 \%$ homology, respectively, with the California WS-RLO (Fig. 4b).

\section{DISCUSSION}

Using methods outlined by the World Animal Health Organization (OIE 2006), we have reported the first observation of the WS-RLO in asymptomatic Haliotis diversicolor in Thailand, Taiwan and the PRC. The morphological and genetic traits of the RLOs from these countries are indistinguishable from the WSRLO described from California. The Asian and Califor- nia RLOs are rod-shaped, measure approximately 300 to $400 \mathrm{~nm}$ by 1500 to $1700 \mathrm{~nm}$, contain ribosomes adjacent to the cell perimeter, and are delimited by a trilaminar cell wall that lacks an apparent peptidoglycan layer (Friedman et al. 2000). Using LM, the RLO inclusions stained a violet to purple color and were situated apical to the nucleus (Friedman et al. 2000). Genetic similarity was high, as evidenced by binding of the WS-RLO ISH probe (Antonio et al. 2000) with the Asian RLO combined with from 99 to $100 \%$ similarity of the amplified $160 \mathrm{bp}$ fragment using published primers specific to WS-RLO (Andree et al. 2000). The $1 \%$ difference ( 1 of $99 \mathrm{bp}$ excluding the primers) in the sequence that was observed between the RLO DNA from Thailand and the RLO from California may be due to polymorphisms in this gene or mutations in the RLO from Thailand compared to the original strain.

We provide evidence that the origin of the RLOs found in our Asian abalone is likely California, USA; the transfer occurred putatively when red abalone seed from a RLO-infected California hatchery was sold to China (R. Gordon, Fish Tech, pers. comm.) in the mid1990s, prior to the development of molecular diagnostic 


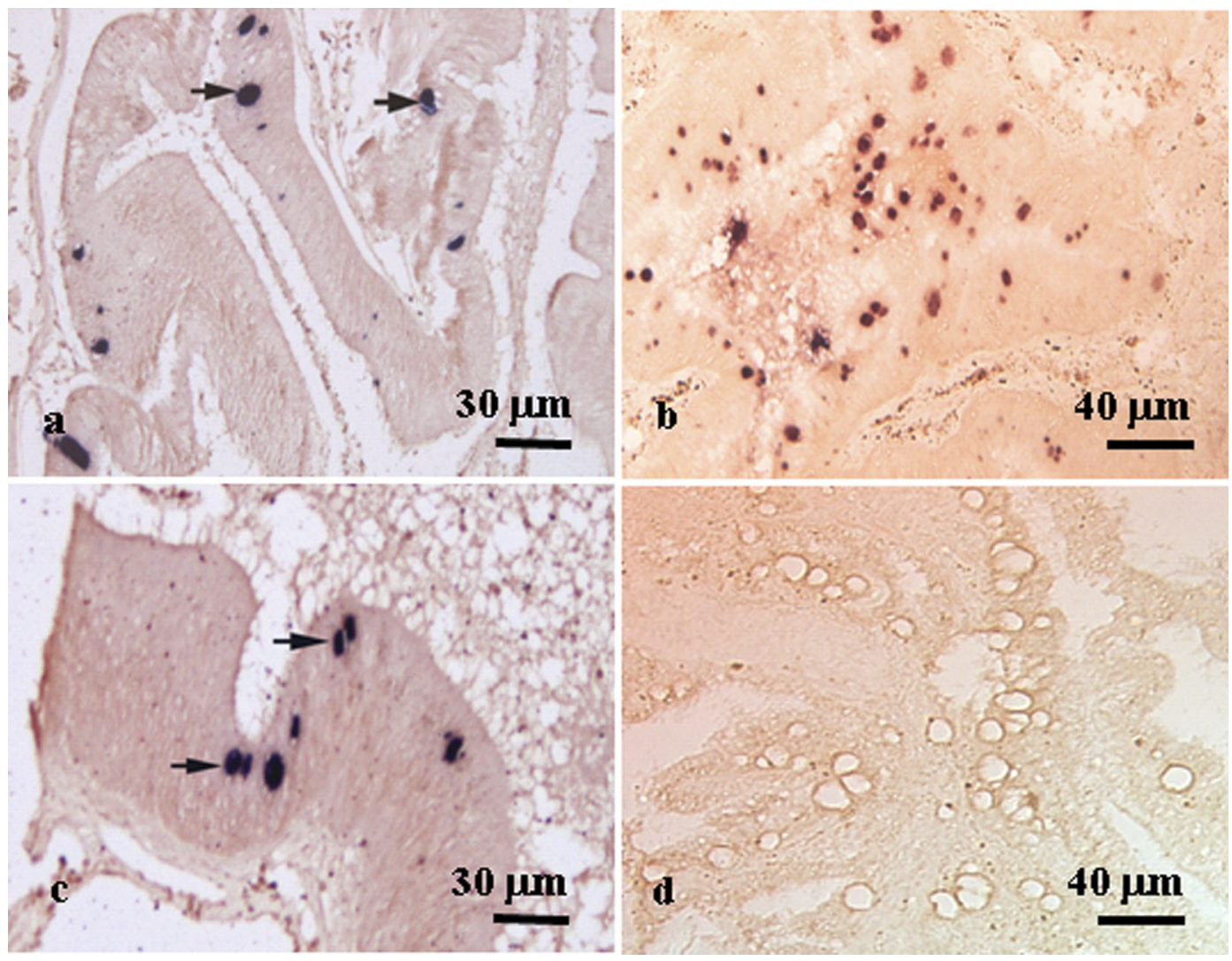

Fig. 2. Haliotis diversicolor supertexta. Photomicrographs of the (a) post-esophagus and (b) intestine of abalone from Thailand processed through in situ hybridization showing positive Rickettsia-like organism (RLO)-primer hybridization as dark brown inclusions. (c) Post-esophagus tissue of RLO-infected H. rufescens shows a positive reaction (arrows). (d) Post-esophagus section from RLO-infected $H$. diversicolor supertexta fully processed through in situ hybridization, except that the 16S rRNA probe was omitted, illustrates a negative reaction

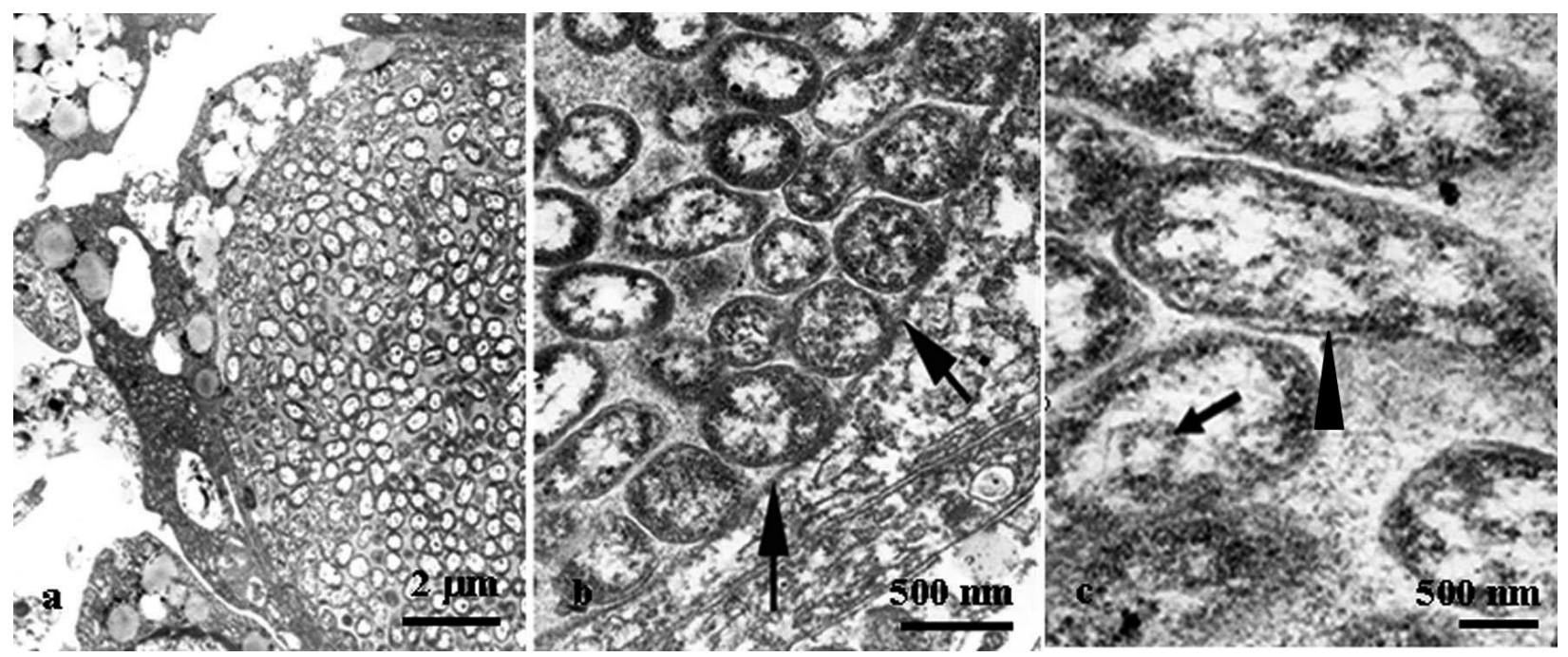

Fig. 3. Haliotis diversicolor supertexta. Transmission electron micrograph of the post-esophagus of abalone from Thailand showing (a) numerous rod-shaped bacteria in cross section, which (b) were localized within membrane-bound vacuoles (arrows). (c) Cell walls of the Rickettsia-like organisms (RLOs) are composed of 3 layers: outer and inner electron-dense layers separated by an electron-lucent layer (arrowhead). A nucleoid structure was observed in some of the bacteria (arrow) 


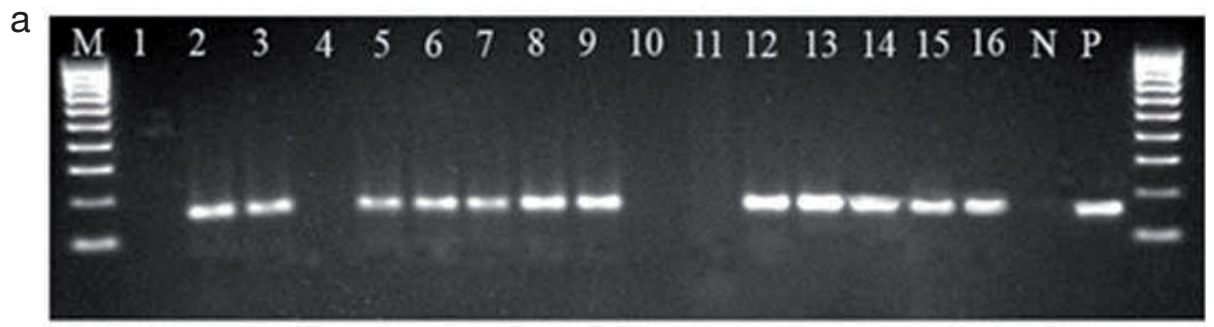

b

\begin{tabular}{|c|c|}
\hline PR China & CGGGTGAGTAATGCTTGGAAATCTACTCAGAAGACATGAATAACTATCAGAAATGGTAGC 60 \\
\hline GenBank & GAAATCTACTCAGAAGACATGAATAACTATCAGAAATGGTAGC 60 \\
\hline Thailand & CGGGTGAGTAATGCTTGGAAATCTACTCAGAAGACATGAATAACTATCAGAAATGATAGC 60 \\
\hline
\end{tabular}

PR China TAATACAAGATAATACCCTGAGGGGGAAAGGTTTATTCC 99

GenBank TAATACAAGATAATACCCTGAGGGGGAAAGGTTTATTCC 99

Thailand TAATACAAGATAATACCCTGAGGGGGAAAGGTTTATTCC 99

$* * * * * * * * * * * * * * * * * * * * * * * * * * * * * * * * * * * * * * *$

Fig. 4. Haliotis diversicolor supertexta. (a) Agarose gel electrophoresis of the amplified products from the post-esophagus of abalone, using primers specific for the 16s rRNA of the withering syndrome-Rickettsia-like organism (WO-RLO). Lane M: 1000 bp DNA molecular marker; Lanes 1 to 16: samples; Lane N: negative control; Lane P: RLO-infected H. rufescens. (b) Sequences of specimens from PR China and Thailand were aligned with those from the USA (available from GenBank; AF133090) via multiple sequence alignments using ClustalW. Asterisks illustrate consensus among sequences

tools. Abalone were, in turn, moved from China to Taiwan in 2000 (B. Withyachumnarnkul pers. comm.). Seed from this same California hatchery has previously been identified as the inadvertent vector for introducing WS-RLO into a natural population in northern California during a restoration study (Rogers-Bennett \& Pearse 1998, Friedman \& Finley 2003). Unlike the infections in many abalone species reported to date, the WSRLOs in our Asian abalone samples were mainly detected in low to moderate numbers within postesophageal epithelia and, in one case, in the intestine, but not in the epithelium of the digestive gland (Gardner et al. 1995, Antonio et al. 2000, Friedman et al. 2000). Low-level infections, particularly in seed abalone, may be difficult to diagnose (Friedman et al. 2007) and may account for the introduction of WS-RLOs via seed abalone from California, despite annual histological examinations of 60 seed (designed to detect parasites at $5 \%$ or greater prevalence; OIE 2006). Our data highlight the imperative for health examinations prior to movement of animals among locations, particularly to distant locations; examinations should be conducted at the $2 \%$ prevalence detection level ( $\mathrm{n}=150$ individuals) and should include both microscopic (histology) and molecular tests (e.g. PCR) when available. Whether or not health examinations were conducted prior to movement of abalone within Asia is not known.

Although WS-RLO-infected Haliotis diversicolor supertexta did not show gross signs of clinical disease in this pilot study and none of the farms contacted reported unusual losses, health examinations prior to animal movements are still needed for successful expansion of aquaculture. Whether a lack of digestive gland metaplasia is a sign of recent infection, host resistance, or due to physiological limitations (e.g. temperature limited) of the RLO is not known at this time. When the $H$. diversicolor supertexta examined in this pilot survey became infected is not known, but infection may have occurred just prior to the examination; however, PCR analysis of this same population of abalone sampled at an earlier life stage (0.35 g BW) also revealed the presence of the infection ( $T$. Wetchateng et al. unpubl. data). Therefore, it is possible that the abalone had been infected by RLOs for at least 9 mo, but were still asymptomatic. The WS-RLO is known to infect juvenile to adult abalones (Haaker et al. 1992, Friedman et al. 1997, 2000, 2007), and all postlarval life stages appear susceptible to the infection (J. D. Moore \& C. S. Friedman unpubl. obs.). The incubation period of WS varies with temperature, but typically ranges from 3 to $7 \mathrm{mo}$, and mortality typically occurs from 1 to 2.5 mo after the onset of visible clinical signs (Friedman et al. 1997). In addition, RLO replication and the associated disease development are enhanced at temperatures $>17^{\circ} \mathrm{C}\left(18\right.$ to $\left.25^{\circ} \mathrm{C}\right)$, suggesting a thermal induction of WS and its RLO (Moore et al. 2000, Braid et al. 2005, Garcia-Esquivel et al. 2007). Metaplasia is commonly observed in WS-RLO-infected abalones held at water temperatures $>18^{\circ} \mathrm{C}$ (Friedman et al. 1997, 2000, 2007). Natural resistance of $H$. diver- 
sicolor supertexta to RLO infection, as compared to most of the highly susceptible cold-water species reported from California, USA (Friedman et al. 2000, 2002, 2007, Moore et al. 2001, 2002), may be another explanation for this observation. Finally, temperatures used to culture $H$. diversicolor supertexta $\left(27\right.$ to $\left.29^{\circ} \mathrm{C}\right)$ may be near the upper limit of the WS-RLO, thereby limiting its ability to cause host metaplasia, advanced infections and clinical disease. Characterization of the thermal tolerance range of the WS-RLO, an obligate intracellular parasite, has been limited by the thermal range of the host abalone species. Infections in $H$. diversicolor supertexta provide an opportunity to further explore the thermal range of the WS-RLO. Further studies on the WS-RLO and $H$. diversicolor supertexta are needed to elucidate the host-parasite relationship.

In conclusion, although the original source of the WS-RLO in Haliotis diversicolor supertexta is not known, we suspect, based on sequence homology and transport history, that it originated from California. Although California abalone were given annual histological health examinations, histology has been shown to be less sensitive than molecular tools in identifying individuals potentially infected with the WS-RLO (Friedman et al. 2007); this may be especially true in small seed abalone. In addition, the abalone reared in Thailand were purchased from Taiwan (B. Withyachumnarnkul pers. comm.), where the cultivation of this species has been practiced for many years, further illustrating the potential anthropogenic movement of this pathogen. Thus, extensive, high-precision health examinations of $H$. diversicolor supertexta should be legally required prior to movement between sites within and outside Thailand, to prevent the spread of this disease as suggested by the OIE (2006) to control aquatic animal diseases (OIE 2006).

Acknowledgements. We thank C. A. Burge, C. Jackels and D. V. Baxa for guiding techniques, R. M. Strenge for data analysis, S. Wongtripop, D. Buranajitpirom and S. Apisawetthanun for assisting with the sample collection, and B. Vadopalas and L. Crosson for editorial comments. Funding for research was provided by the Commission on Higher Educations Scholarship, Thailand, and the School of Aquatic and Fishery Sciences, University of Washington, Seattle, Washington, USA.

\section{LITERATURE CITED}

Altstatt JM, Ambrose RF, Engle JM, Haaker PL, Lafferty KD, Raimondi PT (1996) Recent declines of black abalone Haliotis cracherodii on the mainland coast of central California. Mar Ecol Prog Ser 142:185-192

Andree KB, Friedman CS, Moore JD, Hedrick RP (2000) A polymerase chain-reaction for detection of genomic DNA of a Rickettsiales-like prokaryote associated with withering syndrome in black abalone (Haliotis cracherodii). J Shellfish Res 19:213-218

Antonio DB, Andree KB, Moore JD, Friedman CS, Hedrick RP
(2000) Detection of Rickettsiales-like prokaryotes (RLPs) by in situ hybridization in black abalone Haliotis cracherodii with withering syndrome. J Invertebr Pathol 75: 180-182

Braid BA, Moore JD, Robbins TT, Hedrick RP, Tjeerdema RS, Friedman CS (2005) Health and survival of red abalone, Haliotis rufescens, under varying temperature, food supply, and exposure to the agent of withering syndrome. J Invertebr Pathol 89:219-231

Friedman CS, Finley CA (2003) Evidence for an anthropogenic introduction of 'Candidatus Xenohaliotis californiensis', the etiologic agent of withering syndrome, into northern California abalone populations via conservation efforts. Can J Fish Aquat Sci 60:1424-1431

Friedman CS, Thomson M, Chun C, Haaker PL, Hedrick RP (1997) Withering syndrome of the black abalone, Haliotis cracherodii (Leach): water temperature, food availability, and parasites as possible causes. J Shellfish Res 16: 403-411

Friedman CS, Karl B, Andree KA, Beauchamp KA and others (2000) 'Candidatus Xenohaliotis californiensis', a newly described pathogen of abalone, Haliotis spp., along the west coast of North America. Int J Syst Evol Microbiol 50: 847-855

Friedman CS, Biggs W, Shields JD, Hedrick RP (2002) Transmission of withering syndrome in black abalone, Haliotis cracherodii Leach. J Shellfish Res 21:817-824

Friedman CS, Benjamin BS, Robyn ES, Thomas BM (2007) Oxytetracycline as a tool to manage and prevent losses of the endangered white abalone, Haliotis sorenseni, due to withering syndrome. J Shellfish Res 26:877-885

> Garcia-Esquivel Z, Montes-Magallon S, Gonzales-Gomez MA (2007) Effect of temperature and photoperiod on the growth, feed consumption, and biochemical content of juvenile green abalone, Haliotis fulgens, fed on a balanced diet. Aquaculture 262:129-141

Gardner GR, Harshbarger JC, Lake JL, Sawyer TK and others (1995) Association of prokaryotes with symptomatic appearance of withering syndrome in black abalone, Haliotis crachrodii. J Invertebr Pathol 66:111-120

Haaker PL, Parker H, Togstad DV, Richards DV, Davis GE, Friedman CS (1992) Mass mortality and withering syndrome in black abalone Haliotis cracherodii, in California. In: Shepherd SA, Tegner MJ, Guzman del Proo P (eds) Abalone of the world: biology, fisheries, and culture. Blackwell Science, Oxford, p 214-224

Haaker PL, Karpov K, Rogers-Bennett L, Friedman CS, Tegner NJ (2001) Abalone. In: Leet WS, Dewees CM, Klinbeil R, Larson FJ (eds) California's living marine resources: a status report. University of California Agriculture and Natural Resources Publication SG01-11. California Department of Fish and Game, p 89-97

Jarayabhand P, Poomtong T, Nugranad J (2009) Current status of abalone culture in Thailand. In: Book of abstracts. IAS 2009. The 7th International Abalone Symposium. International Abalone Society, Pattaya, p 10

> Klinbunga S, Amparyup P, Leelatanawit R, Tassanakajon A and others (2004) Species identification of the tropical abalone (Haliotis asinina, Haliotis ovina, and Haliotis varia) in Thailand using RAPD and SCAR markers. J Biochem Mol Biol 37:213-222

Miner CM, Altstatt JM, Raimondi PT, Minchinton TE (2006) Recruitment failure and shifts in community structure following mass mortality limit recovery prospects of black abalone. Mar Ecol Prog Ser 327:107-117

> Moore JD, Robbins TT, Friedman CS (2000) Withering syndrome in farmed red abalone, Haliotis rufescens: thermal 
induction and association with a gastrointestinal Rickettsiales-like procaryote. J Aquat Anim Health 12:26-34

Moore JD, Robbins TT, Hedrick RP, Friedman CS (2001) Transmission of the Rickettsiales-like prokaryote 'Candidatus Xenohaliotis californiensis' and its role in withering syndrome of California abalone. J Shellfish Res 20: 867-874

Moore JD, Finley CA, Robbins TT, Friedman CS (2002) Withering syndrome and restoration of southern California abalone populations. Calif Coop Ocean Fish Invest Rep 43:112-117

Moore JD, Juhasz CI, Robbins TT, Vilchis LI (2009) Green abalone, Haliotis fulgens, infected with the agent of withering syndrome do not express disease signs under a temperature regime permissive for red abalone, Haliotis rufescens. Mar Biol 156:2325-2330

Office Internationale des Epizooties (2006) Infection with Xenohaliotis californiensis. In: Aquatic animal health code, 9th edn. World Organisation for Animal Health, Paris, p 149-154

Rogers-Bennett L, Pearse JS (1998) Experimental seeding of hatchery-reared juvenile red abalone in northern California. J Shellfish Res 17:877-880

Shaw BL, Battle HI (1957) The gross and microscopic anatomy

Editorial responsibility: Mike Hine,

Fouras, France of the digestive tract of the oyster Crassostrea virginica (Gmelin). Can J Zool 35:325-347

Thompson JD, Higgins DG, Gibson TJ (1994) CLUSTAL W: improving the sensitivity of progressive multiple sequence alignment through sequence weighting, position-specific gap penalties and weight matrix choice. Nucleic Acids Res 22:4673-4680

Tinajero MDCA, Caceres-Martinez J, Aviles JGG (2002) Histopathological evaluation of the yellow abalone Haliotis corrugata and the blue abalone Haliotis fulgens from Baja California, Mexico. J Shellfish Res 21:825-830

Tissot BN (1995) Recruitment, growth, and survivorship of black abalone on Santa Cruz Island following mass mortality. Bull South Calif Acad Sci 94:179-189

VanBlaricom GR, Ruediger JL, Friedman CS, Woodard DD, Hedrick RP (1993) Discovery of withering syndrome among black abalone, Haliotis cracherodii Leach, 1814 populations at San Nicholas Island, California. J Shellfish Res 12:185-188

> Vilchis LI, Tegner MJ, Moore JD, Friedman CS, Riser KL, Robbins TT, Dayton PK (2005) Effects of ocean warming on the growth, reproduction and survivorship of red and green abalones in southern California. Ecol Appl 15: $469-480$

Submitted: August 4, 2009; Accepted: March 8, 2010

Proofs received from author(s): May 4, 2010 